\title{
Analisis Kinerja Video Conference pada Jaringan Mobile IPv6 Dengan Triangle Tunneling Method
}

\author{
Muhammad Multazam ${ }^{1)}$, Dwinita Arwidyarti ${ }^{2)}$ \\ STMIK Mataram ${ }^{1,2)}$ \\ sasaktulen@gmail.com ${ }^{1)}$, dwinita.arwidya@gmail.com ${ }^{2)}$
}

\begin{abstract}
Abstrak - Mobile IP merupakan protocol yang mendukung mobilitas dari user, dengan mobile IP sebuah node dapat terus berkomunikasi dengan node yang lain dimanapun dia berada. Mobile IPv6 memperbolehkan node yang telah mempunyai dukungan terhadap IPv6 untuk meninggalkan jaringan asalnya sementara node tersebut sedang memperbarui koneksinya ke internet. Hal ini berarti bahwa mobile IPv6 bisa mengidentifikasi tiap-tiap node dengan static address-nya, tanpa memperhatikan point of attachment nya ke internet.

Mobile IPv6 yang digunakan pada makalah ini memakai metode triangle tunneling yaitu metode perutean pengiriman paket dimana ketika correspondent node $(\mathrm{CN})$ mengirimkan paket menuju mobile node $(\mathrm{MN})$, home agent (HA) mengambil alih paket tersebut dan mengirimkannya ke care of address dari MN dengan tunneling, sedangkan MN dapat mengirimkan langsung menuju CN. Pada makalah ini dilakukan pengujian video conference (multipont) pada jaringan Mobile IPv6 dengan metode triangle tunneling untuk diukur parameter-parameter QoS meliputi packet loss, delay, jitter, throughput dan MOS.

Berdasarkan hasil uji coba dengan memperhatikan parameter-parameter QoS yang dianalisa terlihat bahwa kualitas MN yang berada di jaringan asalnya (homenet) lebih baik ketika berada di jaringan yang sedang dikunjungi (visitnet), hal ini disebabkan dengan metode triangle tunneling paket yang dikirim menuju MN dirutekan ke HA terlebih dahulu sehingga meningkatkan trafik jaringan, selain itu pada uji coba handover terdapat nilai rata-rata delay yang cukup besar yaitu 3.367 detik untuk paket video dan 3.269 detik untuk paket audio, karena pada saat handover, MN membutuhkan waktu untuk memperbaharui koneksi dan melakukan konfigurasi ulang jaringan yang ada.
\end{abstract}

\section{Kata kunci: Video Conference, Mobile IPv6, Triangle Tunneling}

\section{Latar Belakang}

Perkembangan teknologi telekomunikasi mendorong lahirnya suatu inovasi serta kemudahan dalam proses berkomunikasi. Banyaknya pengguna internet pada saat ini membawa keuntungan besar pada teknologi komunikasi nirkabel, tetapi juga menciptakan problem ketika suatu pengguna yang sedang mengakses Internet bergerak dari satu jaringan ke jaringan lain. Dengan adanya mobile IP akses internet menjadi lebih fleksibel terutama dalam keadaan bergerak atau mobile.

Semakin cepat perkembangan teknologi nirkabel mengakibatkan Internet Protocol (IP) versi 4 tidak mampu seiring dengan tuntutan kapasitas dan pengembangan kebutuhan Internet Protocol, sehingga untuk memenuhinya diperlukan versi yang baru, maka muncullah versi 6 . Mobile IP versi 6 merupakan suatu routing protocol yang menyediakan konektivitas untuk peralatan mobile yang menjelajahi antar jaringan IP generasi berikutnya.

Dalam perkembangannya, jaringan mobile IP didesain untuk dapat menggunakan layanan pada
non-Mobile IP salah satunya adalah video conference. Kebutuhan akan layanan video conference belakangan ini menunjukkan peningkatan yang cukup signifikan. Teknologi ini dimanfaatkan di dalam dunia bisnis, pemerintahan, multimedia, pendidikan, maupun dunia jurnalistik untuk melakukan wawancara jarak jauh. Videoconference berbasis IP merupakan suatu layanan yang memungkinkan dua orang atau lebih melakukan konferensi tanpa harus bertatap muka secara langsung. Dengan memanfaatkan jaringan mobile IP, video conference dapat dilakukan dalam keadaan bergerak.

Makalah ini mengimplementasikan layanan video conference pada jaringan mobile IPv6 dengan menggunakan metode triangle tunneling yang merupakan basic routing yang dipakai oleh sistem mobile IP dan mengevaluasi kinerja atau performansi dari video conference dengan cara mengukur serta menganalisa parameterparameter QoS (Quality of Service) dan MOS (Mean Opinion Score). Proses pengiriman paket pada makalah ini menggunakan metode triangle 
tunneling yaitu metode pengiriman dimana paket data yang berasal dari Corespondent Node (CN) dikirimkan menuju Mobile Node (MN) melewati Home Agent (HA) kemudian Mobile Node (MN) mengirim balasan kepada Corespondent Node (CN) secara langsung tersebut memperbolehkan tiap-tiap coresspondent node menggunakan layer di atas mobile IPv6.

Layer yang lebih tinggi (termasuk layer aplikasi) tanpa melihat care of address, dengan hanien malihnt Unmo ndirzss.

Gambar 1 Operasi Mobile IPv6

\section{Tinjauan Pustaka}

\section{a. Metode Triangle Tunneling}

Secara umum operasi pada mobile IPv6 dapat dilihat pada Gambar 1.

Gambar 1 menunjukkan bahwa ada 3 link dan 3 sistem. Pada link A yang berada pada router yang mempunyai service sebagai Home agent. Link A juga berperan sebagai Home link dari mobile node. Mobile node berpindah dari link $A$ ke link B. Node tambahan adalah node $C$ yang berperan sebagai coresspondent node.

Saat Home agent menerima paket yang dialamatkan pada Home address dari mobile node dengan menggunakan mekanisme "Proxy Neighbour Discovery" yang berarti bahwa Home agent mengirimkan pesan multicast berupa neighbour advertisement ke semua host pada Home link atas nama mobile node. Pesan ini berisi alamat link layer dari Home agent kepada Home address dari mobile node. Selanjutnya Home agent akan membalas dengan mengirimkan pesan berupa neighbour solicitation atas nama mobile node. Tiap-tiap paket yang diterima selanjutnya akan dikirimkan melalui sebuah terowongan (tunnel) ke alamat care of address dari mobile node dengan menggunakan mekanisme enkapsulasi paket IPv6.

Jika mobile node mengirimkan paket ke node yang lain, mobile node akan mengirimkan paket secara langsung ke node yang dituju. Mobile node akan melakukan setting pada source address dari paket tersebut, termasuk pada opsi destination Home address. Dikarenakan Home address menggunakan model pengalamatan statis (berbeda dengan care of address yang menggunakan dinamis), sehingga dengan alasan
Gambar 2 menunjukkan jika mobile node berkomunikasi dengan correspondent node ketika sedang berada jauh dari Home linknya, paket akan diteruskan dari correspondent node ke Home agent, dari Home agent ke mobile node dan dari mobile node ke correspondent node. Routing ini biasanya disebut dengan Triangle routing atau Triangle tunneling (Sohaib, 2004).

Home agent menerima paket yang dialamatkan ke mobile node Home address menggunakan proxy neighbour discovery. Selanjutnya paket dari mobile node yang dikirim dari care of address akan diterima oleh Home agent melalu tunnel ketika mobile node sedang berada pada jaringan asing.

Kemudian mobile node mengkonfigurasi care of address yang diterima sebagai care of address utama, harus mendaftarkan alamat barunya ke Home agent dan ke correspondent node dengan mengirimkan binding update yang berisi binding baru. Untuk meyakinkan bahwa paket benarbenar diterima oleh node yang diinginkan, mobile node dapat "memaksa" penerima untuk memberikan informasi adanya binding update yang diterima dengan mengirimkan kembali binding Ack. Untuk trigger Ack, mobile node meletakkan setting pada Ack bit di dalam binding update. Mobile node akan terus mengirimkan binding update sampai diterimanya binding update.

\section{b. Pengukuran Delay}

Didefinisikan sebagai penundaan yang mengakibatkan keterlambatan paket datang ke 
penerima. Dalam aplikasi video conference, delay merupakan salah satu permasalahan yang harus diperhitungkan karena kualitas suara dan gambar sangat tergantung dari waktu delay yang terjadi.

Besarnya delay maksimum yang direkomendasikan oleh ITU-T adalah $100 \mathrm{~ms}$ (ITU-T Recommendation Y.1541, 2006).

Beberapa delay yang dapat mengganggu kualitas suara dan gambar dalam perencanaan jaringan Video Conference dapat dikelompokkan menjadi:

1. Propagation delay (delay yang terjadi akibat transmisi melalui jarak antar pengirim dan penerima)

2. Serialization delay (delay pada saat proses peletakan bit ke dalam circuit)

3. Processing delay (delay yang terjadi saat proses coding, compression, decompression dan decoding)

4. Packetization delay (delay yang terjadi saat proses paketisasi digital voice sample)

5. Queuing delay (delay akibat waktu tunggu paket sampai dilayani)

6. Jitter buffer (delay akibat adanya buffer untuk mengatasi jitter)

Selain itu parameter-parameter lain yang mempengaruhi Quality of Service (QoS), agar didapatkan hasil suara dan gambar dengan kualitas yang baik, antara lain:

1. Pemenuhan kebutuhan bandwidth

2. Keterlambatan data (latency)

3. Packet loss

4. Jenis kompresi data

5. Interopabilitas peralatan (vendor yang berbeda)

6. Jenis standar multimedia yang digunakan

Untuk berkomunikasi dengan menggunakan teknologi video conference yang harus diperhatikan adalah delay, jitter dan loss packet.

\section{c. Pengukuran Jitter}

Jitter merupakan variasi delay yang terjadi akibat adanya selisih waktu atau interval antar kedatangan paket di penerima. Untuk mengatasi jitter maka paket data yang datang dikumpulkan dulu dalam jitter buffer selama waktu yang telah ditentukan sampai paket dapat diterima pada sisi penerima dengan urutan yang benar. Akan tetapi dengan adanya jitter buffer akan menambah jumlah dari end-to-end delay, untuk kualitas suara jitter yang diperbolehkan adalah kurang dari 50 $\mathrm{ms}$, sedangkan untuk kualitas gambar $75 \mathrm{~ms}$ (ITU-T Recommendation Y.1541, 2006).
Salah satu alternatif solusi permasalahan di atas adalah membangun link antar node pada jaringan dengan spesifikasi dan dimensi dengan QoS yang baik dan dapat mengantisipasi perubahan lonjakan trafik hingga pada suatu batas tertentu.

\section{d. Pengamatan Packet Loss}

Packet loss merupakan hilangnya paket dalam jaringan yang disebabkan faktor antrian (queue) yang melebihi batas waktu yang ditentukan atau ukuran paket yang terlalu besar sehingga tidak mungkin ditransmisikan dalam jaringan yang kecepatannya rendah.

Pengamatan paket dilakukan dengan cara mengamati jumlah paket yang dikirim maupun yang diterima oleh masing-masing client yang melalui protokol TCP/IP dan yang sangat penting dalam pengamatan paket adalah adanya packet loss saat melakukan komunikasi dengan menggunakan video conference (ITU-T Recommendation H.261). Saat terjadi paket loss suara dan gambar yang terjadi pada sisi penerima menjadi terputus-putus, paket loss disebabkan karena delay yang terlalu besar.

Loss packet (kehilangan paket) terjadi ketika peak load dan congestion (kemacetan transmisi paket akibat padatnya traffic yang harus dilayani) dalam batas waktu tertentu, maka frame (gabungan data payload dan header yang di transmisikan) suara akan dibuang sebagaimana perlakuan terhadap frame data lainnya pada jaringan berbasis IP. Untuk mengetahui nilai packet loss yang diperbolehkan dapat dilihat pada Tabel 1.

\section{e. Pengukuran Throughput}

Throughput adalah jumlah bit yang diterima dengan sukses perdetik melalui sebuah sistem atau media komunikasi. Throughput diukur setelah transmisi data (host/client) karena suatu sistem akan menambah delay yang disebabkan processor limitations, kongesti jaringan, buffering inefficients, error transmisi, traffic loads atau mungkin desain hardware yang tidak mencukupi.

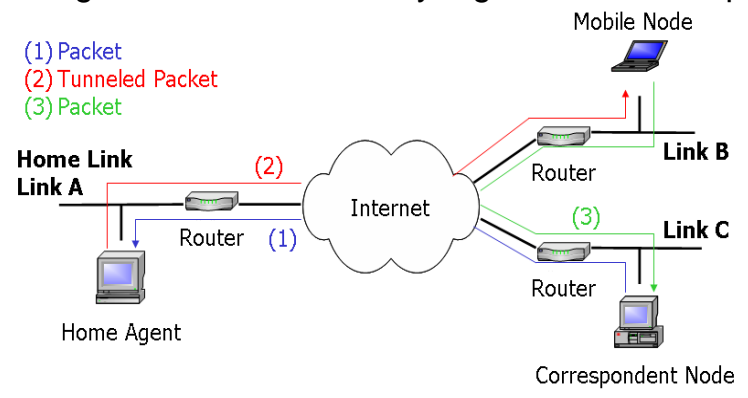

Gambar 2 Mekanisme Triangle 
Tabel 1 IP Network Performance Objective

\begin{tabular}{|l|c|c|}
\hline \multicolumn{1}{|c|}{ Network parameter } & Audio & Video \\
\hline Transfer delay & $100 \mathrm{~ms}$ & $150 \mathrm{~ms}$ \\
\hline Variation Delay (jitter) & $50 \mathrm{~ms}$ & $75 \mathrm{~ms}$ \\
\hline Packet loss & $1 \%$ & $1 \%$ \\
\hline
\end{tabular}

(ITU-T Recommendation Y.1541, 2006)

Aspek utama throughput yaitu berkisar pada ketersediaan bandwidth yang cukup untuk menjalankan aplikasi. Hal ini menentukan besarnya trafik yang dapat diperoleh suatu aplikasi saat melewati jaringan. Aspek penting lainnya adalah error (pada umumnya berhubungan dengan link error rate) dan losses (pada umumnya berhubungan dengan kapasitas buffer).

Throughput tergantung pada faktor-faktor berikut ini:

1. Karakteristik link: bandwidth, error rate.

2. Karakteristik node: kapasitas buffer, daya pemrosesan.

\section{f. Kualitas Gambar dan Suara}

Kualitas gambar dan suara merupakan faktor utama yang secara langsung bisa dilihat dan didengar oleh pengguna untuk menyatakan kepuasan atas apa yang dihasilkan dari video conference dan salah satu cara yang digunakan untuk penentuan kualitas gambar dan suara adalah penilaian subjektif dari responden, dengan memberikan dengan menggunakan penilaian kualitas sebesar skala 5 sebagai Mean Opinion Score (MOS) atau nilai opini pendengar di penerima, sebagai berikut (ITU-T Recommendation P-805):

$$
\text { Nilai: } \begin{aligned}
: & \rightarrow \text { Bad (Jelek) } \\
& 2 \rightarrow \text { Poor (Kurang Bagus) } \\
& 3 \rightarrow \text { Fair (Sedang) } \\
& 4 \rightarrow \text { Good (Bagus) } \\
& 5 \rightarrow \text { Excellent (Sangat }
\end{aligned}
$$

\section{Analisa Data dan Pembahasan \\ a. Packet Loss Video}

Pembebanan dilakukan dengan memberikan variasi pembebanan nilai bitrate yang dibebankan kepada server, yaitu sebesar $15 \mathrm{Mbps}, 30 \mathrm{Mbps}$ dan 50 Mbps.

Gambar 3 menunjukan grafik rata-rata dari packet loss video pada pengukuran server video conference di jaringan mobile IPv6, terlihat bahwa semakin besar bitrate yang dibebankan kepada server MCU packet loss video semakin besar. Untuk pengukuran yang terkoneksi dengan dua client nilai packet loss dalam kondisi tanpa beban adalah sebesar $0.12 \%$ (sd: 0.09 ).

Sedangkan untuk pengukuran dengan tiga client terkoneksi nilai packet loss tanpa beban adalah $0.14 \%$ (sd: 0.08 ).

Nilai packet loss paling besar didapat ketika diberi pembebanan bitrate $50 \mathrm{Mbps}$ yaitu sebesar $1.51 \%$ (sd: 0.99) untuk server yang terkoneksi dua client dan $2.16 \%$ (sd:1.31) untuk server yang terkoneksi tiga client. Berdasarkan pengamatan pada saat ujicoba nilai packet loss yang besar menyebabkan gambar terputus-putus.

\section{b. Packet Loss Audio}

Packet loss untuk audio pada pengukuran server video conference dapat dilihat pada Tabel 4.2 dibawah ini. Kompresi audio yang digunakan adalah G.711.

Dari Gambar 4 dapat dilihat adanya kenaikan yang signifikan terhadap nilai packet loss audio yaitu pada server yang terkoneksi tiga client ketika dibebani dengan bitrate sebesar 50 Mbps yaitu mencapai $1.69 \%$ (sd: 0.27). hal ini menunjukan bahwa dengan adanya pembebanan nilai packet loss audio akan bertambah besar.

Salah satu penyebab utama hilangnya paket RTP ini adalah delay atau latency serta kongesti yang terlalu besar dalam jaringan tersebut, berdasarkan pengamatan pada saat ujicoba nilai packet loss yang besar menyebabkan suara yang terputus-putus pada saat komunikasi.

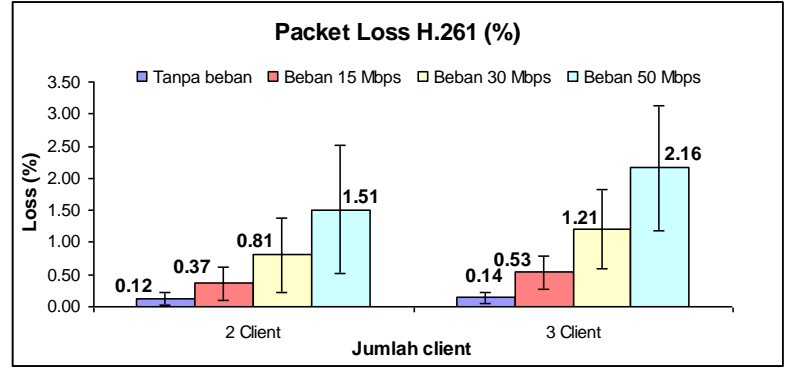

Gambar 3 Grafik Packet Loss H.261 Pengujian Server Video Conference

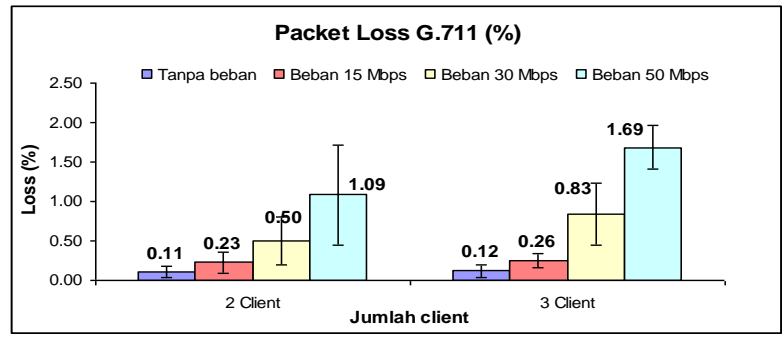

Gambar 4 Grafik Packet Loss G.711 Pengujian c. Delay Video 
Dari grafik pada Gambar 5 menunjukkan peningkatan delay video yang cukup signifikan seiring dengan bertambahnya beban. Pada pengukuran server terkoneksi dua client nilai delay video dengan kondisi tanpa beban adalah $42.69 \mathrm{~ms}$ (sd: 6.01) sedangkan pada server terkoneksi tiga client adalah $43.08 \mathrm{~ms}$ (sd: 5.06). Ketika dilakukan pembebanan delay video meningkat hingga $88.34 \mathrm{~ms}$ (sd: 28.19) pada server terkoneksi dua client dan $92.20 \mathrm{~ms}$ (sd: 24.71) pada server terkoneksi tiga client. Berdasarkan pengamatan pada saat ujicoba kondisi delay yang besar menyebabkan komunikasi video conference terputus-putus.

\section{d. Delay Audio}

Dari Gambar 5 dan Gambar 6 hasil pengamatan delay audio pada pengukuran server video conference mempunyai nilai yang lebih kecil dibandingkan nilai pengamatan pada delay video, hal ini disebabkan karena besar paket audio lebih kecil daripada paket video sehingga delay yang disebabkan juga lebih kecil.

Besarnya pembebanan membuat delay yang dihasilkan ikut bertambah dimana delay video maksimum yang dihasilkan mencapai $41.08 \mathrm{~ms}$ (sd: 6.52) pada server yang terkoneksi tiga client dan $37.05 \mathrm{~ms}$ (sd: 6.35) pada server yang terkoneksi dua client pada saat dibebani bitrate 50 Mbps. Sedangkan untuk kondisi tanpa beban delay audio yang dihasilkan $\pm 30 \mathrm{~ms}$.

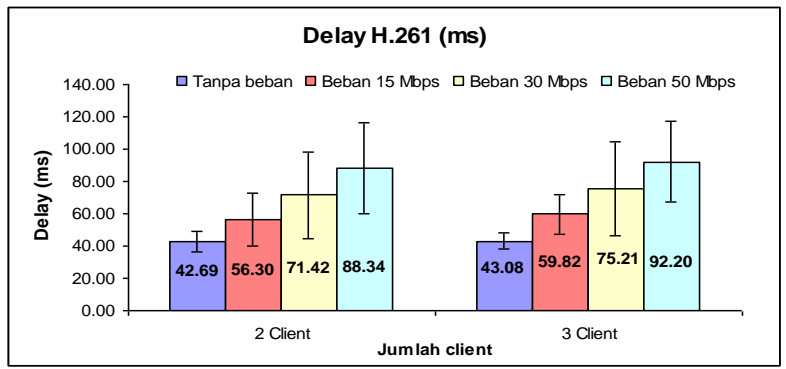

Gambar 5 Grafik Delay H.261 Pengujian Server Video Conference

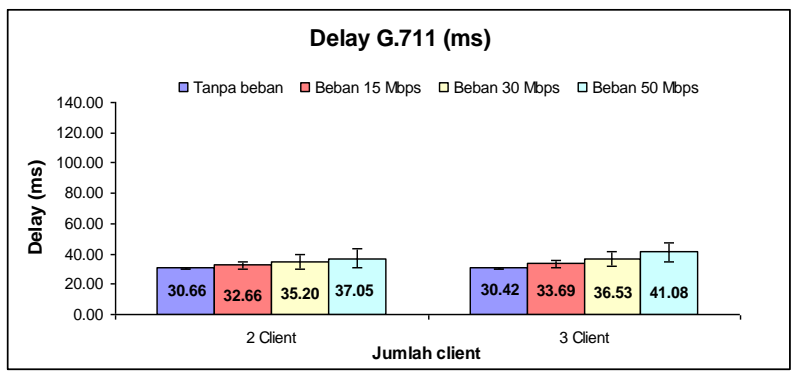

Gambar 6 Grafik Delay G.711 Pengujian Server Video Conference
Dari grafik pada Gambar 7 dapat dilihat bahwa nilai jitter video pada kondisi tanpa beban yang diperoleh adalah sebesar $28.43 \mathrm{~ms}$ (sd: 4.65) untuk server yang terkoneksi dua client dan 29.96 $\mathrm{ms}$ (sd:4.11) untuk server yang terkoneksi tiga client.

Nilai jitter video maksimum diperoleh ketika dilakukan pembebanan sebesar 50 Mbps mencapai $61.59 \mathrm{~ms}$ (sd: 19.89) pada server yang terkoneksi dua client dan $63.12 \mathrm{~ms}$ (sd:16.19), hal ini menunjukan bahwa nilai jitter video cenderung meningkat ketika dilakukan pembebanan. Kondisi server terkoneksi dua client dan server terkoneksi tiga client mempunyai nilai jitter paket video yang hampir sama.

\section{f. Jitter Audio}

Gambar 8 menunjukan nilai rata-rata jitter audio (G.711) pada pengukuran server video conference dan dapat dilihat nilai jitter audio bertambah ketika dilakukan pembebanan, nilai jitter maximum diperoleh saat server dibebani beban dengan bitrate 50 Mbps dan terjadi perbedaan yang cukup besar yaitu $5.02 \mathrm{~ms}$ (sd: 2.35) pada server yang terkoneksi dua client dan 6.06 (sd: 2.63) pada server yang terkoneksi tiga client, berbeda degan kondisi pembebanan sebelumnya. Pada saat kondisi tanpa pembebanan jitter audio pada server yang terkoneksi dua client dan server yang terkoneksi tiga client mempunyai nilai rata-rata yang sama yaitu sebesar $2.06 \mathrm{~ms}$.

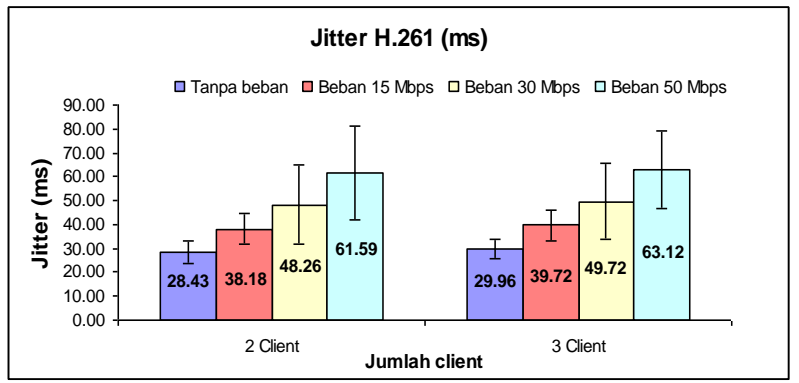

Gambar 7 Grafik Jitter H.261 Pengujian Server Video Conference

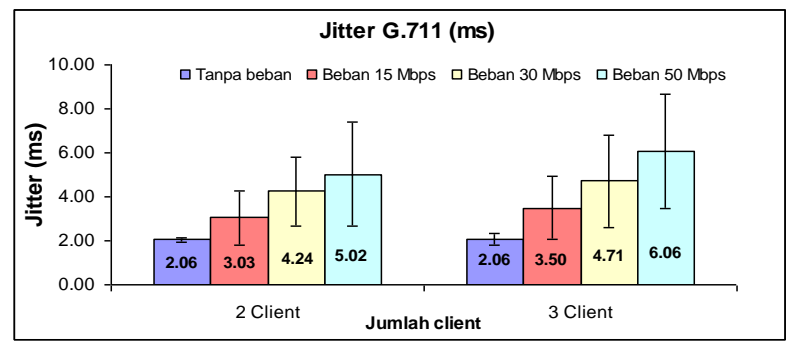

Gambar 8 Grafik Jitter G.711 Pengujian Server Video Conference

\section{e. Jitter Video}




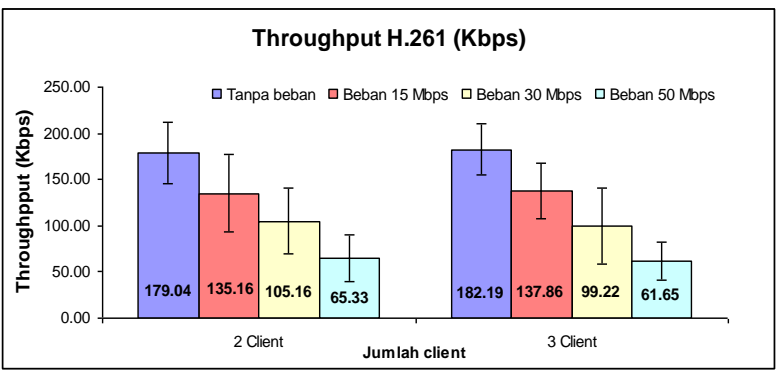

Gambar 9 Grafik Throughput H.261 Pengujian Server Video Conference

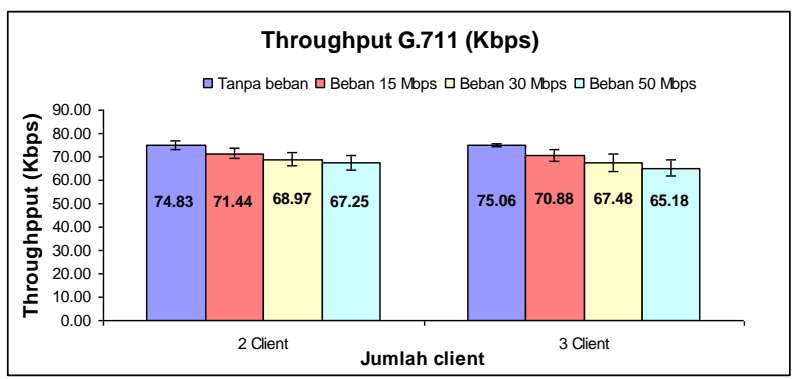

Gambar 10 Grafik Throughput G.711 Pengujian Server Video Conference

\section{g. Throughput Video}

Berdasarkan grafik pada Gambar 9 besarnya nilai throughput yang dialokasikan untuk video pada kondisi server terkoneksi tiga client sekitar 61.65 kbps (sd: 20.44) sampai 182.19 kbps (sd: 27.56) dan untuk server terkoneksi dua client sekitar 65.33 kbps (sd: 25.41) sampai 170.04 kbps (sd: 33.72). Pembebanan yang dilakukan pada server menyebabkan nilai throughput berkurang, Nilai throughput terendah diperoleh ketika diberi beban dengan bitrate 50 Mbps. Secara keseluruhan nilai throughput video pada kondisi server terkoneksi dua client lebih besar daripada ketika server terkoneksi tiga client.

\section{h. Throughput Audio}

Berdasarkan data diperoleh grafik rata-rata dari throughput audio pada Gambar 10. Besarnya nilai throughput yang dialokasikan untuk audio pada kondisi server terkoneksi tiga client sekitar 65.18 kbps (sd: 3.39) sampai 75.06 kbps (sd: 0.55) dan untuk server terkoneksi dua client sekitar $67.25 \mathrm{kbps}$ (sd: 25.41) sampai $74.83 \mathrm{kbps}$ (sd: 1.86).

Pembebanan yang dilakukan pada server menyebabkan nilai throughput paket audio (G.711) berkurang, nilai throughput audio terendah diperoleh ketika diberi pembebanan dengan bitrate $50 \mathrm{Mbps}$.

\section{i. MOS Pengujian Server Video Conference}

Dari hasil polling yang dilakukan pada sepuluh orang responden, didapatkan nilai kualitas gambar dan suara seperti pada Tabel 2.

Tabel 2 menunjukkan bahwa rata-rata nilai MOS untuk video conference pada jaringan mobile IPv6 yang menggunakan 2 client relatif bagus dibandingkan dengan 3 client baik untuk kualitas gambar maupun suara. Berdasarkan tabel nilai MOS terendah diperoleh ketika pembebanan 50 Mbps.

\section{j. MOS Pengujian MN (Mobile node)}

Dari hasil polling yang dilakukan pada sepuluh orang responden, didapatkan nilai kualitas gambar dan suara untuk pengukuran $\mathrm{MN}$ di jaringan homenet dan visitnet serta pada saat handover, dilakukan juga perbandingan terhadap client-client non-mobile. Tabel 3 menunjukkan bahwa rata-rata nilai MOS untuk kualitas gambar dan suara client non-mobile lebih bagus daripada MN.

MN di homenet mempunyai nilai MOS yang sedikit lebih bagus daripada MN di visitnet baik untuk kualitas gambar maupun suara. Untuk pengujian handover walaupun terdapat delay yang cukup besar tetapi penilaian responden terhadap MN cukup memuaskan.

Tabel 2 Rata-rata MOS Pengujiran Server Video Conference

\begin{tabular}{|c|c|c|c|c|c|}
\hline Jumlah User & Payload & Tanpa beban & 15 Mbps & 30 Mbps & 50 Mbps \\
\hline 2 client & \multirow{2}{*}{ H.261 } & 3.97 & 3.59 & 2.67 & 2.14 \\
\cline { 3 - 6 } & & 3.94 & 3.70 & 2.54 & 1.94 \\
\hline 3 client & \multirow{2}{*}{ G.711 } & 4.05 & 3.38 & 2.84 & 2.39 \\
\cline { 3 - 6 } & & 3.98 & 3.28 & 2.73 & 2.31 \\
\hline 3 client & &
\end{tabular}

Tabel 3 Rata-rata MOS pada MN dan Client Video Conference

\begin{tabular}{|c|c|c|c|c|c|}
\hline Jenis Client & Payload & Tanpa beban & $15 \mathrm{Mbps}$ & 30 Mbps & $50 \mathrm{Mbps}$ \\
\hline MN homenet & \multirow{5}{*}{ H.261 } & \begin{tabular}{|l|}
3.83 \\
\end{tabular} & 3.44 & 2.47 & 2.03 \\
\hline MN visitnet & & 3.72 & 3.49 & 2.32 & 1.77 \\
\hline MN Handover & & 3.57 & 3.37 & 2.20 & 1.75 \\
\hline Client 2 & & 4.13 & 3.88 & 3.26 & 2.34 \\
\hline Client 3 & & 4.14 & 3.64 & 2.86 & 1.90 \\
\hline MN homenet & \multirow{5}{*}{ G.711 } & 3.85 & 3.27 & 2.70 & 2.27 \\
\hline MN visitnet & & 3.74 & 3.18 & 2.50 & 2.06 \\
\hline MN Handover & & 3.59 & 3.15 & 2.32 & 1.78 \\
\hline Client 2 & & 4.10 & 3.85 & 3.11 & 2.38 \\
\hline Client 3 & & 4.01 & 3.39 & 2.51 & 2.28 \\
\hline
\end{tabular}

\section{Penutup}

a. Kesimpulan

Beberapa kesimpulan yang dapat diambil setelah penelitian adalah sebagai berikut:

1. Dari hasil pengujian video conference, packet loss $\mathrm{MN}$ di visitnet memiliki nilai paling besar diantara yang lain yaitu sebesar $0.40 \%$ untuk video dan $0.37 \%$ untuk audio pada kondisi tanpa beban, namun packet loss masih dapat 
ditoleransi karena batas maksimum packet loss RTP adalah sebesar $1 \%$. Packet loss bertambah besar seiring dengan penambahan beban.

2. Pada pengujian handover, jumlah paket yang hilang bertambah yaitu mencapai $2.72 \%$ untuk video dan $3.23 \%$ untuk audio, disebabkan karena pada saat handover MN mengalami kehilangan koneksi sementara.

3. Throughput dipengaruhi oleh besarnya packet loss. Dari hasil pengujian, MN di homenet memiliki rata-rata throughput yang lebih besar daripada visitnet yaitu 148.99 kbps untuk video dan 75.01 kbps untuk audio sedangkan pada visitnet nilainya $134.29 \mathrm{kbps}$ untuk video dan 72.83 kbps untuk audio. Kondisi ini dikarenakan dengan metode triangle tunneling, trafik di jaringan meningkat dan menyebabkan banyak paket yang hilang.

4. Throughput pada saat handover mengalami penurunan yang drastis yaitu mencapai 7.54 kbps untuk video dan 11.2 kbps untuk audio, hal ini disebabkan oleh besarnya packet loss.

5. Delay MN di visitnet mencapai 56.52 ms untuk video dan 38.32 ms untuk audio, sedangkan MN di homenet delay-nya lebih kecil yaitu $48.54 \mathrm{~ms}$ untuk video dan 30.79 ms untuk audio, hal ini dikarenakan dengan triangle tunneling pengiriman paket menuju MN dirutekan ke HA terlebih dahulu. Namun secara keseluruhan delay yang diperoleh masih dibawah standard ITU yaitu 100 ms.

6. Untuk pengujian handover, delay maksimum yang diperoleh sangat besar yaitu mencapai $3.367 \mathrm{~s}$ untuk video dan $3.269 \mathrm{~s}$ untuk audio, hal ini dikarenakan butuh waktu bagi MN untuk memperbaharui koneksi dan melakukan konfigurasi ulang jaringan yang ada. Kemudian jitter yag diperoleh mencapai 66.76 ms untuk video dan 4.49 ms untuk audio. Untuk paket video, jitter yang diperoleh melebihi standar ITU

7. Jitter pada pengujian $\mathrm{MN}$ di visitnet mencapai 39.74 ms untuk video dan $2.22 \mathrm{~ms}$ untuk audio pada kondisi tanpa beban, sedangkan $\mathrm{MN}$ di homenet memiliki jitter sebesar 34.30 ms untuk video dan $2 \mathrm{~ms}$ untuk audio lebih kecil daripada MN di homenet hal ini dikarenakan delay MN di visitnet juga besar. Namun jitter yang diperoleh masih dibawah standar ITU yaitu $50 \mathrm{~ms}$ untuk suara dan $75 \mathrm{~ms}$ untuk gambar.

8. Penilaian menggunakan MOS pada pengujian MN di homenet lebih baik daripada pengujian MN di visitnet, baik dengan kondisi tanpa beban maupun dibebani, sedangkan MOS untuk pengujian handover cukup baik walaupun terdapat delay cukup besar.

9. Hasil pengukuran monitoring pada server memperlihatkan bahwa jumlah client yang terkoneksi mempengaruhi kualitas video conference. tanpa beban maupun dibebani, sedangkan MOS untuk pengujian handover cukup baik walaupun terdapat delay cukup besar.

\section{b. Saran}

Hal yang dapat menjadi pertimbangan/saran untuk pengembangan penelitian selanjutnya adalah:

1. Agar menghasilkan kualitas video conference lebih baik digunakan hardware MCU khusus yang dapat mensupport IPv6.

2. Untuk penelitian selanjutnya topology perancangan sistem video conference dibuat lebih kompleks.

3. Untuk pengembangan dari sisi system, perlunya menambah jumlah home agent dan foreign agent di jaringan.

4. Untuk memudahkan proses handover perlunya pembuatan monitoring-system yang berbasis GUI pada MN (Mobile Node).

5. Untuk perbaikan kualitas handover dapat mencoba metode handover yang lebih baik seperti fast handover.

6. Untuk pengembangan mobile IP, diperlukan mencoba metode tunneling atau routing lain yang dapat meningkatkan kualitas.

\section{Pustaka}

Chul-Ho Lee, Dongwook Lee, and JongWon Kim "MPEG-4 Video Streaming over Mobile IP-enabled Wireless LAN", Kwang-Ju Institute of Science and Technology (KJIST), Gwangju, Korea, 2004

C. Perkins, "IP Mobility Support," RFC 2002, IETF, October 1996.

Hanane Fathi, Shyam S. Chakraborty, Ramjee Prasad, "Optimization of Mobile IPv6-Based Handovers to Support VolP Services in Wireless Heterogeneous Networks", IEEE TRANSACTIONS ON VEHICULAR TECHNOLOGY, January 2007

Gnomemeeting H.323 software, http://www.gnomemeeting.org

Hans-Peter Schwefel, "Performance Analysis of Hand-over Mechanisms", Aalborg University, CNTK Workshop, 2004

Hasanul Ferdaus, Sazzadur Rahman, Kamrul Islam, "Comparative Analysis of Mobility Support in Mobile IP and SIP", Proceedings Of World Academy Of 
Science, Engineering And Technology, November 2005

Hitesh Tewari, Donal O'Mahony, "Real-Time Payments for Mobile IP", Trinity College Dublin, IEEE Communications Magazine, February 2003

ITU-T Recommendation G.711, "Pulse Code Modulation (PCM) of Frequencies", Voice T/publications http://www.itu.int/ITU-

ITU-T Recommendation H.261, "Video Codec for Audiovisual Services at $\mathrm{p} \times 64$ bits", http://www.itu.int/ITU-T/publications

ITU-T Recommendation H.323, "Packet-based multimedia communications systems", http://www.itu.int/lTU-T/publications

ITU-T Recommendation Y.1541, 2006, "Network performance objective for IP-based services", http://www.itu.int/ITUT/publications

ITU-T P-805, Subjective evaluation of conversational quality, http://www.itu.int/ITU-T/publications

John Fitzpatrick, Seán Murphy, Mohammed Atiquzzaman, John Murphy, "Evaluation of VolP in a Mobile Environment using an end-to-end Handoff Mechanism", University College Dublin, Ireland, 2006

Mobile IPv6 software, http://www.mipv6.org

Rafiudin, Rahmat, "IPv6 Addressing", Elex Media Komputindo Jakarta. 2005

RFC 1890, "RTP Profile for Audio and Video Conferences with Minimal Control", http://www.ietf.org

RFC 2002, "IP Mobility Support", www.ietf.org

RFC 3775, June 2004, "Mobility Support in IPv6", www.ietf.org

RFC 791, "Internet Protocol", http://www.ietf.org Sohaib Mahmood, "Triangle Routing in Mobile IP", Lahore University of Management Science Pakistan, 2004

Soonuk Seol, Myungchul Kim, Chansu Yu, JongHyun Lee, "Experiments and Analysis of Voice over Mobile IP", Cleveland State University. 